\author{
Michak Buszko* \\ Uniwersytet Mikołaja Kopernika w Toruniu
}

\title{
WALUTOWE KREDYTY MIESZKANIOWE A KURSY WALUTOWE - OCENA RYZYKA
}

Słowa kluczowe: euro, frank szwajcarski, ryzyko walutowe, walutowe kredyty mieszkaniowe.

\begin{abstract}
Abstrakt: Celem artykułu jest ocena walutowych kredytów mieszkaniowych udzielonych przez banki w Polsce. W ramach pracy badawczej przeprowadzono analizę portfela kredytów mieszkaniowych, ustalono jego strukturę, w tym w zakresie rodzaju walut oraz zmiany. Ponadto w ramach pracy przeprowadzono analizę opłacalności kredytowania walutowego względem momentu otrzymania kredytu. Na potrzeby niniejszej pracy przeprowadzono również analizę statystyczną zmienności kursów franka szwajcarskiego oraz euro, a także ustalono korelacje kursów i zmienności na tle innych walut wymienialnych wycenianych w Polsce. Badania wykazały wysoką zarówno krótko-, jak i długoterminową zmienność kursu franka na tle euro i innych walut oraz potwierdziły wysoki poziom ryzyka kredytowania w walucie szwajcarskiej.
\end{abstract}

\section{FOREIGN CURRENCY HOUSING LOANS AND EXCHANGE RATES - RISK EVALUATION}

Keywords: euro, foreign exchange housing loans, fx risk, swiss franc.

Abstract: The aim of this paper is an evaluation of foreign exchange housing loans granted in Poland. In the paper, there was conducted research of portfolio of housing loans, its structure and changes, especially with consideration to the currency of debts. Also, a foreign currency loans profitability accordingly to the time of obtaining the loan by the debtor was analyzed. The author statistically analyzed volatility of foreign exchange rates of major currencies traded in Poland. The results were compared versus

Data wpłynięcia: 22.11.2012; data zaakceptowania: 25.02.2013.

* Dane kontaktowe: mibus@econ.uni.torun.pl, Katedra Zarządzania Finansami, Wydział Nauk Ekonomicznych i Zarządzania, Uniwersytet Mikołaja Kopernika, ul. Gagarina 13a, 87-100 Toruń, tel. 566114634. 
swiss franc and euro. The research indicated very high level of swiss franc volatility and risk as well as confirmed high level of risk of financing in swiss currency over euro.

Translated by Michał Buszko

\section{II WSTĘP}

W 2005 r. rozpoczął się w Polsce okres dynamicznego rozwoju rynku nieruchomości, stymulowany $\mathrm{w}$ dużej mierze korzystnymi warunkami makroekonomicznymi oraz łagodną polityką kredytową banków. Wzrastające wynagrodzenia, wysokie tempo wzrostu PKB oraz bardzo dobra koniunktura gospodarcza zachęcały do podjęcia decyzji w sprawie zakupu mieszkań, tym bardziej że popyt na nie od kilku dekad pozostawał permanentnie niezaspokojony. Zakup mieszkania czy domu niewątpliwie ułatwiały banki, łagodząc zasady udzielania kredytów hipotecznych, przeznaczając na nie coraz większe zasoby kapitału, jak również akceptując coraz większe ryzyko kredytowe oraz rynkowe. Banki, zmierzając do sprzedaży jak największej liczby kredytów, w szczególności w warunkach zaostrzającej się konkurencji, zaczęły w sposób sztuczny podnosić zdolność kredytową klientów przez udzielanie kredytów w niskooprocentowanych walutach obcych, wydłużanie okresu kredytowania oraz akceptację wskaźnika LTV na poziomie $100 \%$ i powyżej. W okresie 2-3 lat polityka ta doprowadziła do znaczącego dopływu pieniądza na rynek nieruchomości i szybkiego wzrostu cen. W konsekwencji osoby kupujące nieruchomości musiały decydować się na zaciąganie kredytów o bardzo wysokich wartościach przy braku realnego długoterminowego zabezpieczenia swojej sytuacji finansowej. Jednocześnie masowo zaczęto decydować się na finansowanie w walutach obcych, zwłaszcza we franku szwajcarskim, co w okresie 2006-2008 wydawało się rozwiązaniem zdecydowanie tańszym niż kredyt w walucie krajowej.

Zdominowanie rynku kredytów mieszkaniowych finansowaniem we franku szwajcarskim spowodowało pojawienie się szeregu problemów zarówno po stronie klientów, jak i banków. Chociaż kredyty walutowe były zaciągane ze względu na znacząco niższe oprocentowanie w stosunku do polskiego złotego, to kredytowanie w latach 2007-2008 odbywało się przy bardzo niskim kursie obcych walut, generując bardzo duże ryzyko kursowe. W praktyce ryzyko to zmaterializowało się już pod koniec 2008 i na początku 2009 r. Z punktu widzenia banków dominacja kredytów udzielanych w walucie spowodowała utworzenie znaczącej zagranicznej ekspozycji kapitałowej oraz uzależnienie 
od finansowania na międzynarodowym rynku finansowym. W efekcie już na początku kryzysu finansowego pod koniec 2008 r. podmioty te stanęły przed problemem refinansowania oraz zabezpieczenia płynności w walutach obcych. Banki udzielające kredytów walutowych zostały również narażone na praktycznie niekontrolowany wzrost zadłużenia klientów z tytułu wzrostu wartości walut przy równoległym spadku cen zabezpieczających je nieruchomości. Jednocześnie wzrost wartości kredy tów walutowych w przeliczeniu na polskie złote spowodował konieczność pozyskania dodatkowych funduszy własnych i dokapitalizowania banków. Z punktu widzenia klientów kredytowanie w walutach obcych, dające początkowo duże korzyści, zaczęło wiązać się z koniecznością płacenia coraz wyższych rat. Zmniejszeniu uległa zatem ich siła nabywcza oraz wzrosło łączne zadłużenie w przeliczeniu na polskie złote. Dodatkowo wobec spadku cen nieruchomości kredytobiorcy pozostali z niezabezpieczoną wartością długu, co w przypadku przedterminowego zakończenia umowy będzie skutkowało niewypłacalnością.

Ze względu na istotny udział kredytów hipotecznych denominowanych w walutach obcych w polskim systemie finansowym, daleko idące konsekwencje tego rodzaju kredytowania, jak również uzależnienie kondycji finansowej kredytobiorców oraz kredytodawców od sytuacji na rynku walutowym celem niniejszego opracowania ${ }^{1}$ jest analiza i ocena ryzyka kursowego determinującego opłacalność i zmienność obciążenia spłatą rozważanych kredytów. Za pomocą odchylenia kursu od mediany zostanie przeprowadzona analiza opłacalności kredytów walutowych we franku szwajcarskim i euro w zależności od poziomu kursu walutowego występującego w momencie ich zaciągania. Ponadto, za pomocą głównych miar zmienności (odchylenia standardowego, rozstępu oraz współczynnika zmienności), uzupełnionych o oscylator prezentujący względne natężenie zmienności, zostanie przeprowadzone badanie ryzyka rynkowego wybranych walut, determinującego obciążenie spłatami rat kredytów. Na potrzeby pracy zostanie również wykorzystana statystyka opisowa oraz korelacje porządku rang Spearmana między kursami, jak i zmiennością kursów głównych walut wycenianych w Polsce w okresie styczeń 2004-wrzesień 2012, mających na celu ustalenie współzależności między wyceną różnych walut w Polsce oraz możliwością przenoszenia ryzyka między nimi. Ponieważ w niniejszym opracowaniu skoncentrowano się przede wszystkim na problematyce oceny ryzyka z punktu widzenia kredytobiorców (klientów banków),

${ }^{1}$ Niniejszy artykuł powstał przy dofinansowaniu ze środków grantu WNEiZ 1180-E. 
pominięto tu metody pomiaru ryzyka stosowane przez instytucje finansowe, w tym miary wrażliwości i zagrożenia.

\section{WALUTOWE KREDYTY MIESZKANIOWE W SEKTORZE BANKOWYM W POLSCE}

Kredyty denominowane lub indeksowane do walut obcych stanowią w Polsce znaczący udział w portfelu kredytowym banków. W okresie zwłaszcza pierwszej dekady XXI w. można było obserwować ich bardzo szybki przyrost w sektorze bankowym. W 2005 r., a więc na początku intensywnego rozwoju rynku nieruchomości w Polsce, miały one wartość ok. 68,6 mld zł, stanowiąc ok. 26,7\% wartości portfela wszystkich kredytów. Ważny jest przy tym fakt, że w wymienionym roku przewagę miały kredyty walutowe udzielane przedsiębiorstwom z tytułu rozliczenia transakcji zagranicznych. Już od 2006 r. ten stan uległ zmianie i główną składową portfela kredytów walutowych stały się kredyty hipoteczne udzielane gospodarstwom domowym na cele mieszkaniowe (Buszko 2010: 11). Od tego momentu segment kredytów walutowych zaczął odzwierciedlać przede wszystkim sytuację w segmencie mieszkaniowym, a cały portfel kredytowy sektora stał się istotnie zależny od sytuacji na międzynarodowym rynku finansowym oraz od wyceny polskiego złotego względem franka szwajcarskiego. W 2011 r. wartość kredytów walutowych osiągnęła rekordowy poziom 306,9 mld zł, stanowiąc 33,7\% całego portfela ${ }^{2}$. Chociaż boom na rynku nieruchomości oraz wzrost cen zostały wyhamowane pod koniec 2008 r., w Polsce następował dalszy przyrost wartości portfela kredytów walutowych, przy czym jednym z najważniejszych czynników wzrostu było silne osłabienie polskiego złotego względem walut obcych, zwłaszcza franka szwajcarskiego ${ }^{3}$.

Wśród kredytów walutowych od 2006 r. dominujący udział mają kredyty mieszkaniowe udzielane gospodarstwom domowym. Wartość i udział kredytów denominowanych w walutach obcych w kredytach mieszkaniowych oraz w kredytach dla gospodarstw domowych ogółem przedstawia tabela 1.

2 Po pierwszym półroczu 2012 r. odnotowano spadek ich wartości do poziomu 294 mld zł, co stanowiło 31,8\% wartości kredy tów sektora.

${ }^{3}$ W okresie sierpień 2011-luty 2012 odnotowano według kursu średniego NBP historycznie wysokie poziomy wyceny: CHF - 3, 9562 (11.08.2011), CZK - 0,1810 (23.09.2011), NOK - 0,5920 (13.12.2011), SEK - 0,5098 (5.01.2012), 100 JPY - 4,5731 (6.01.2012). 
Tabela 1. Walutowe kredyty mieszkaniowe

a kredyty gospodarstw domowych (mld zł; \%)

\begin{tabular}{|l|c|c|c|c|c|c|c|c|c|c|c|c|c|}
\hline \hline \multicolumn{1}{|c|}{ Rok } & $\mathbf{2 0 0 5}$ & $\begin{array}{c}\text { Zmiana } \\
\%\end{array}$ & $\mathbf{2 0 0 6}$ & $\begin{array}{c}\text { Zmiana } \\
\%\end{array}$ & $\mathbf{2 0 0 7}$ & $\begin{array}{c}\text { Zmiana } \\
\%\end{array}$ & $\mathbf{2 0 0 8}$ & $\begin{array}{c}\text { Zmiana } \\
\%\end{array}$ & $\mathbf{2 0 0 9}$ & $\begin{array}{c}\text { Zmia- } \\
\text { na \% }\end{array}$ & $\mathbf{2 0 1 0}$ & $\begin{array}{c}\text { Zmia- } \\
\text { na \% }\end{array}$ & $\mathbf{2 0 1 1}$ \\
\hline \hline $\begin{array}{l}\text { Walutowe } \\
\text { kredyty } \\
\text { mieszk. }\end{array}$ & 32,2 & $\begin{array}{c}55,28 \\
(57,47)^{*}\end{array}$ & 50,0 & $\begin{array}{c}30,20 \\
(33,31)\end{array}$ & 65,1 & $\begin{array}{c}108,91 \\
(84,03)\end{array}$ & 136,0 & $\begin{array}{c}4,49 \\
(4,54)\end{array}$ & 142,1 & $\begin{array}{c}19,14 \\
(17,05)\end{array}$ & 169,3 & $\begin{array}{c}16,83 \\
(14,73)\end{array}$ & 197,8 \\
\hline $\begin{array}{l}\text { Kredyty } \\
\text { mieszk. } \\
\text { razem }\end{array}$ & 50,7 & 54,24 & 78,2 & 50,51 & 117,7 & 65,76 & 195,1 & 11,64 & 217,8 & 22,82 & 267,5 & 19,18 & 318,8 \\
\hline $\begin{array}{l}\text { Udział } \\
\text { kredytów } \\
\text { walut } \\
\text { w kredytach } \\
\text { mieszk. }\end{array}$ & 63,51 & 0,67 & 63,94 & $-13,49$ & 55,31 & 26,03 & 69,71 & $-6,40$ & 65,24 & $-2,99$ & 63,29 & $-1,97$ & 62,05 \\
\hline $\begin{array}{l}\text { Kredyty } \\
\text { dla gospo- } \\
\text { darstw } \\
\text { domowych }\end{array}$ & 136,4 & 34,46 & 183,4 & 38,60 & 254,2 & 46,50 & 372,4 & 11,82 & 416,4 & 14,17 & 475,4 & 11,91 & 532,0 \\
\hline $\begin{array}{l}\text { Kredyty } \\
\text { ogółem }\end{array}$ & 258,5 & 24,87 & 322,8 & 32,43 & 427,5 & 52,89 & 653,6 & 9,23 & 713,9 & 10,31 & 787,5 & 15,72 & 911,3 \\
\hline \hline
\end{tabular}

* Zmiana podana w nawiasie oznacza tempo zmiany wartości kredytów skorygowane o zmianę kursu walutowego CHF/PLN. Od 2009 r., ze względu na wzrost znaczenia euro jako waluty kredytowania, tempo jest korygowane o zmianę wartości koszyka walut CHF i EUR ustaloną zgodnie z ich udziałem w portfelu kredytowym sektora.

Źr ó d ł o : opracowanie własne na podstawie: Raport o sytuacji banków w 2008 r., Urząd Komisji Nadzoru Finansowego, Warszawa 2009; Raport o sytuacji banków w 2009 r., Urząd Komisji Nadzoru Finansowego, Warszawa 2010; Raport o sytuacji banków w 2010 r., Urząd Komisji Nadzoru Finansowego, Warszawa 2011; Raport o sytuacji banków w 2011 r., Urząd Komisji Nadzoru Finansowego, Warszawa 2012.

Zaprezentowane dane wskazują na bardzo silny przyrost wartości kredytów w walutach obcych w 2008 r. oraz utrzymujące się permanentnie dodatnie, aczkolwiek słabnące, tempo jej wzrostu po silnych zawirowaniach na rynkach finansowych z okresu 2008-2009. Wraz ze spadkiem tempa kredytowania w walutach obcych spadał również udział tych kredytów w kredytach mieszkaniowych ogółem, a także zmieniała się struktura walutowa, tzn. wzrastał udział euro kosztem franka. W okresie 2008-2011 wartość kredytów mieszkaniowych w walucie szwajcarskiej i ich udział w portfelu kredytów walutowych wynosiły odpowiednio: 131,9 mld zł (97,00\%), 132,9 mld zł (93,53\%), 147,4 mld zł (87,06\%), 163,5 mld zł (82,66\%). Tendencji spadkowej finansowa- 
nia we franku odpowiadał wzrost udziału euro ${ }^{4}$. Wartość i udział kredytów w euro w okresie 2008-2011 wynosiły odpowiednio: 2,6 mld zł (1,9\%), 7,6 mld zł (5,3\%), 19,7 mld zł (11,6\%) i 31,9 mld zł (16,13\%). Zjawisko zastępowania franka przez euro było efektem wycofywania się coraz większej liczby banków z finansowania we franku oraz przewalutowania zobowiązań w szwajcarskiej walucie na euro.

Biorąc pod uwagę skalę, znaczenie i konsekwencje kredytów mieszkaniowych udzielanych gospodarstwom domowym w walutach obcych, należy wskazać na ich kilka charakterystycznych cech odnotowanych według stanu z $2011 \mathrm{r}$.

W portfelu kredytów mieszkaniowych denominowanych we franku szwajcarskim największy udział według wartości bilansowej miały długi o wartości przekraczającej 500 tys. zł $(36,56 \%)$ oraz długi w przedziale 200-300 tys. zł $(16,56 \%)$. Podobne zjawisko było widoczne w portfelu kredytowym dla euro, gdzie udział zadłużenia powyżej 500 tys. zł stanowi 37,14\%. Niemniej jednak w odróżnieniu od waluty szwajcarskiej, drugi udział przypadł na długi o wartości w przedziale 300-400 tys. zł (19,05\%). W portfelu kredytów mieszkaniowych udzielonych $\mathrm{w}$ polskich złotych przeważały kredyty o wartości bilansowej w przedziale $100-200$ tys. zł $(30,45 \%)$ oraz $200-300$ tys. zł $(23,10 \%)$ (Raport o sytuacji banków w 2011 r. 2012).

Pod względem okresu zapadalności w przypadku wszystkich trzech walut dominował co do zasady bardzo długi okres kredytowania, zwykle przekraczający 25 lat. W przypadku franka szwajcarskiego przeważały długi o okresie spłaty 25-30 lat, dla których łączna wartość ekspozycji wynosiła 63,6 mld zł (39,02\% wartości portfela). Drugie miejsce pod względem wartości bilansowej miały kredyty o okresie spłaty 20-25 lat, z tytułu których zadłużenie wynosiło 37,7 mld zł $(23,13 \%)$. Dla waluty euro kredyty koncentrujące największą wartość - 18,5 mld zł - również były udzielane na okres 25-30 lat i stanowiły $58,73 \%$ portfela. Drugie pod względem wartości były kredyty o okresie zapadalności powyżej 30 lat - 5,1 mld zł, stanowiące 16,19\% portfela. W portfelu kredytów mieszkaniowych udzielonych w polskim złotym w 2011 r. dominowały długi o terminie zapadalności 25-30 lat, które osiągnęły poziom 49,8 mld zł (43,08\%). Drugie w kolejności były kredyty o okresie spłaty 10-20 lat, koncentrujące 26,7 mld zł (23,10\%) (Raport o sytuacji banków w 2011 r. 2012).

${ }^{4}$ Pozostałe waluty obce nie odgrywają większej roli w kredytowaniu mieszkań w Polsce. 
Biorąc pod uwagę wartość wskaźnika LTV w portfelu kredytów mieszkaniowych sektora bankowego, można zauważyć duże zróżnicowanie między walutami. W przypadku franka dominowały ekspozycje powyżej 130\%, które stanowiły w 2011 r. łącznie 48,7 mld zł (29,88\%). Dla wymienionej waluty znaczący udział miały również ekspozycje o LTV poniżej 70\% - 43,3 mld zł (26,56\%). W przypadku euro dominowały ekspozycje poniżej 70\% - 7,6 mld zł $(24,13 \%)$, aczkolwiek znaczącą wartość generowały również ekspozycje o wskaźniku $100-110 \%-5,7$ mld zł (18,10\%) oraz $90-100 \%-5,6$ mld zł $(17,78 \%)$. W przypadku polskiego złotego zdecydowanie największy udział miały kredyty charakteryzujące się wskaźnikiem LTV poniżej 70\% - 59,3 mld zł (51,30\%). Znacznie mniejszy udział przypadł drugim w kolejności kredytom o wskaźniku 90-100\% - 17,6 mld zł (15,22\%) (Raport o sytuacji banków w 2011 r. 2012).

Podsumowując właściwości walutowych kredytów mieszkaniowych, można stwierdzić, że kredyty te charakteryzują się wysokimi wartościami pojedynczych ekspozycji, bardzo długim czasem kredytowania oraz bardzo wysokim poziomem wartości zadłużenia w stosunku do wartości zabezpieczających ich nieruchomości (LTV). W przypadku kredytów we franku wysoka wartość pojedynczych długów oraz dominacja kredytów o wskaźniku LTV powyżej 130\% powinna być przypisana nie tyle kredytowaniu wyłącznie nieruchomości o wysokiej wartości czy zbyt liberalnej polityce finansowania przyjętej przez banki, ale przede wszystkim wzrostowi kursu franka w okresie 2008-2011. Wysoki udział ekspozycji walutowych we franku i euro o wskaźniku LTV poniżej 70\% należy przypisać kredytom zaciąganym przed okresem boomu na rynku nieruchomości, a więc sprzed 2007 r., kiedy banki stosowały znacznie bardziej konserwatywną politykę kredytową, a ceny nieruchomości były istotnie niższe.

Na koniec 2011 r. wartość zagrożonych walutowych kredytów mieszkaniowych pozostawała generalnie niska (3,2 mld zł), co stanowiło 1,6\% wartości portfela walutowych ekspozycji mieszkaniowych. Większą wartość długu zagrożonego odnotowano w przypadku ekspozycji w polskim złotym (4,3 mld zł), co stanowiło 3,52\% portfela mieszkaniowego w PLN (Raport o sytuacji banków w I półroczu 2012 r. 2012). Mimo że zagrożone ekspozycje dewizowe osiągnęły niższą wartość niż kredyty w walucie krajowej, to należy mieć na uwadze, że rzeczywista jakość kredytów we franku czy euro może być niższa niż kredytów w polskim złotym. W przypadku nieregularnych kredytów walutowych zwyczajowo następuje ich przewalutowanie na polskie złote lub postawienie w stan wymagalności w polskich złotych. Również w obecnych warunkach 
rynkowych kredyty te praktycznie nie podlegają przedterminowej spłacie, co oznacza, że w momencie zmiany warunków rynkowych (znaczny spadek kursu franka czy euro) może nastąpić skokowy wzrost wartości pozostających kredytów zagrożonych. Ponadto niski udział kredytów zagrożonych może być wynikiem cały czas przyrastającej wartości ogółu kredytów walutowych z tytułu nowych długów.

\section{KURS WALUTOWY A OPŁACALNOŚĆ MIESZKANIOWYCH KREDYTÓW WALUTOWYCH}

Zdominowanie rynku kredytów mieszkaniowych w Polsce przez ekspozycje $\mathrm{w}$ walutach obcych powoduje istotny wzrost ryzyka rynkowego w systemie bankowym, zarówno po stronie banków, jak i ich klientów (Buszko 2011: 8). Zakładając, że w długim horyzoncie rynek walutowy będzie sprowadzał wartość kursu do poziomu odzwierciedlającego wartość fundamentalną gospodarki polskiej na tle innych gospodarek, można przyjąć, że docelową wartością franka szwajcarskiego i euro w Polsce będą ich wieloletnie mediany. Jeżeli przyjmie się do analizy okres 1.01.1999-30.09.2012, mediany kursu CHF/PLN i EUR/PLN wyniosą odpowiednio 4,0240 oraz 2,6677. Biorąc pod uwagę okres najbardziej aktywnego kredytowania w walutach obcych (2006-2008), można ustalić względną wartość zysków lub strat w stosunku do wartości kredytu w zależności od kursu, po jakim rozpoczęto kredytowanie (wykres 1).

Wykres 1. Opłacalność kredytów walutowych w zależności od poziomu kursu walutowego (2006-2008)

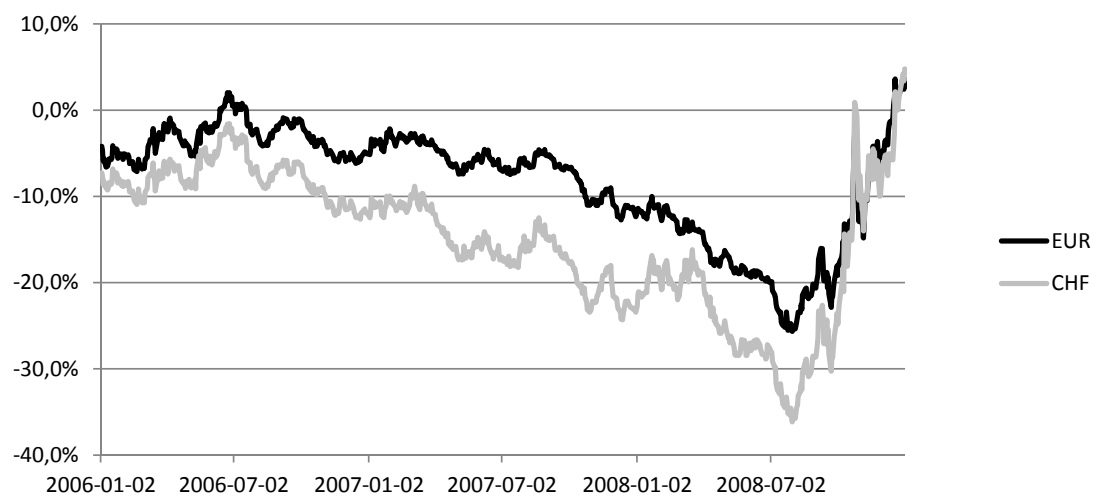

Źr ó d ło : opracowanie własne na podstawie średnich kursów walutowych NBP. 
Z uwagi na poziom kursu w momencie rozpoczęcia kredytowania właściwie w całym okresie wzrostu rynku nieruchomości (2006-2008) kredyty walutowe były udzielane ze szkodą dla klientów banków. Mniejsze straty względem mediany kursu ponosili przy tym kredytobiorcy zaciągający kredyty w euro. Zdecydowanie najgorszym okresem na zaciąganie kredytów walutowych był miesiąc lipiec $2008 \mathrm{r}$.

\section{KURS WALUTOWY A RYZYKO MIESZKANIOWYCH KREDYTÓW WALUTOWYCH}

Walutowe kredyty mieszkaniowe udzielone w Polsce we franku i euro zasadniczo uzależniają wartość spłaty oraz zdolność kredytową klientów od bieżącego kursu walutowego. W przypadku znaczących wahań wyceny walut obcych na rynku finansowym kredytobiorcy nie są w stanie zaplanować wydatków z tytułu spłaty rat kredytu. W sytuacji długotrwałego utrzymywania się wysokiej wartości walut obcych w stosunku do waluty krajowej ryzyko walutowe będzie mogło zmaterializować się w postaci ryzyka kredy towego, powodując z jednej strony niewypłacalność klientów banku, a z drugiej - brak realnej możliwości odzyskania środków kredytu z tytułu zabezpieczenia hipotecznego. Zmienność kursu euro i franka mierzoną odchyleniem standardowym liczonym ze 100 dziennych stóp zmiany kursu przedstawia wykres 2 .

Wykres 2. Zmienność kursu euro i franka w okresie 2004-2012

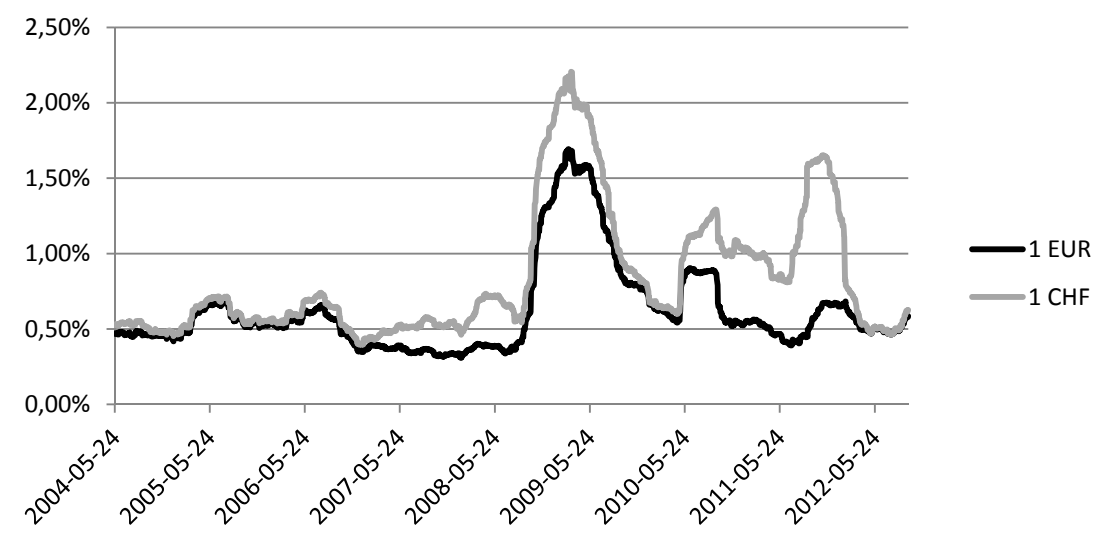

Źr ó d ł o : opracowanie własne na podstawie średnich kursów NBP. 
Względną zmienność kursu (oscylator zmienności) liczoną jako moduł dziennej stopy zmiany kursu do modułu maksymalnej wartości dziennej zmiany kursu dla euro i franka przedstawia wykres 3.

Wykres 3. Względna zmienność kursu euro i franka

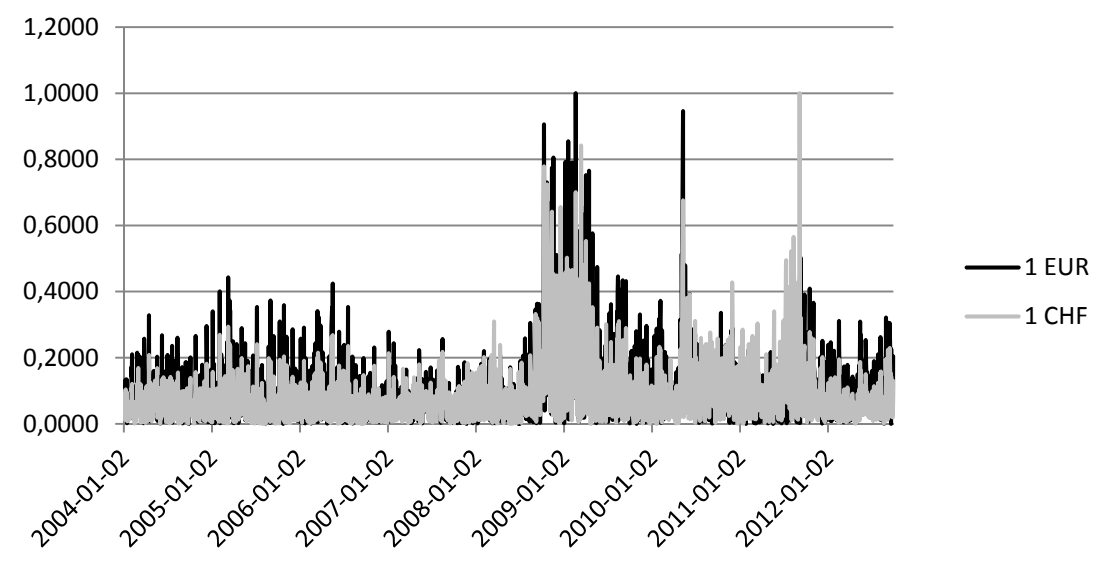

Ź r ó d ł o : opracowanie własne na podstawie średnich kursów NBP.

Przedstawione dane dla obu walut wskazują na trzy okresy podwyższonej zmienności, tzn. sierpień 2008-styczeń 2010, maj 2010-listopad 2010 oraz lipiec 2011-marzec 2012. Pierwszy był efektem kryzysu subprime, kolejne dwa - trudnej sytuacji finansów publicznych części krajów strefy euro (zwłaszcza Grecji). We wszystkich okresach większą zmienność mierzoną odchyleniem standardowym wykazywał frank szwajcarski, największe pojedyncze względne zmiany kursów odnotowano dla euro w pierwszym i drugim okresie podwyższonej zmienności, natomiast dla franka w pierwszym i trzecim.

\section{WALUTY KREDYTOWANIA MIESZKANIOWEGO A INNE WALUTY}

Oceniając ryzyko związane z kredytowaniem mieszkań w walutach obcych, warto porównać charakterystyki rynkowe franka i euro z parametrami walut innych krajów wysokorozwiniętych. Ogólną charakterystykę głównych walut wycenianych w Polsce w okresie styczeń 2004-wrzesień 2012 przedstawia tabela 2 . 


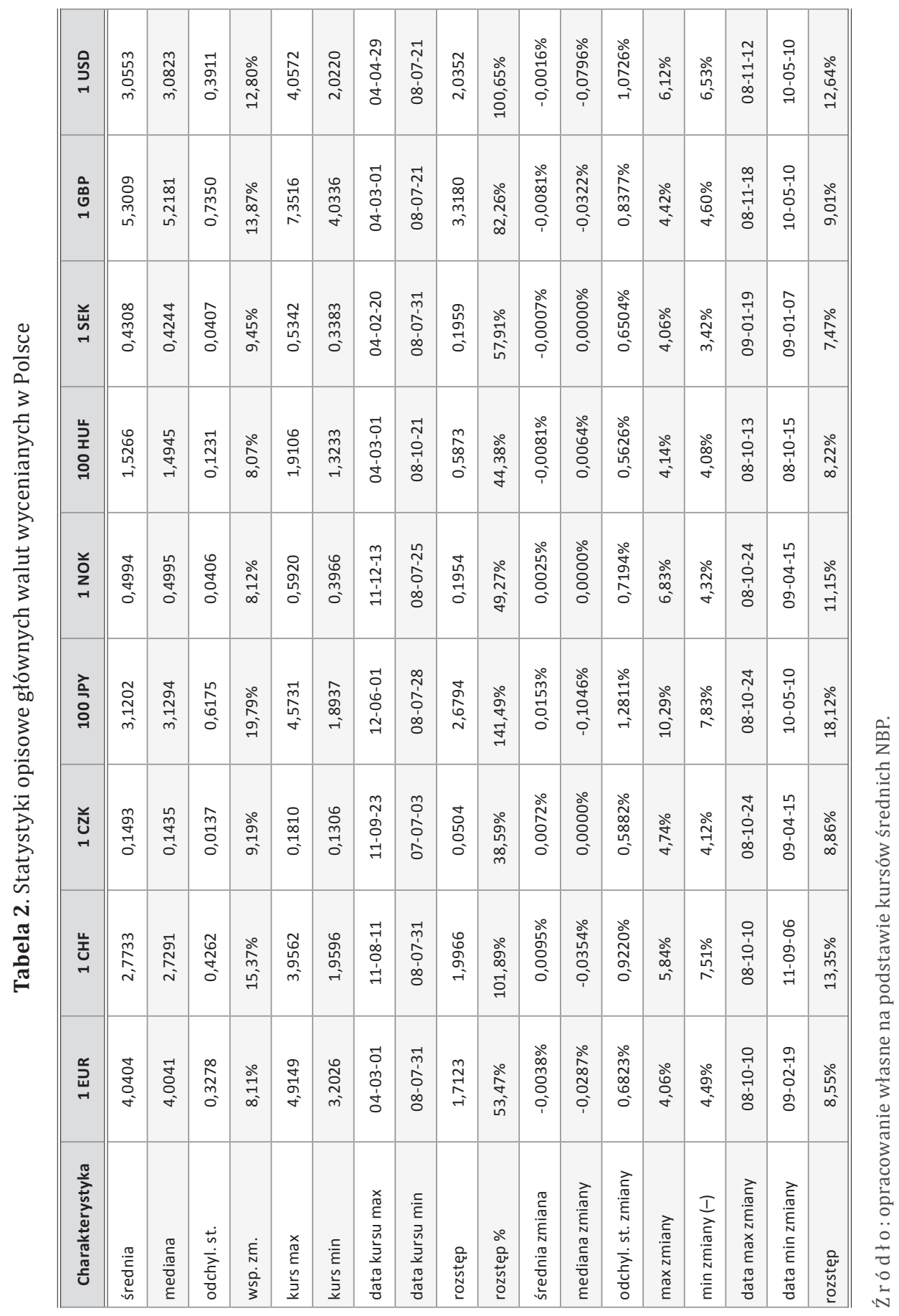


Na podstawie przedstawionych statystyk można wnioskować, że w długim horyzoncie frank szwajcarski jest jedną z najbardziej ryzykownych walut wycenianych w Polsce. Udzielanie kredytu w tej walucie oznacza zatem możliwość występowania znacznej różnicy wartości zobowiązań klienta w stosunku do banku zarówno w krótkim, jak i długim terminie.

Ryzyko walutowe związane z kredytami mieszkaniowymi denominowanymi w walutach obcych można oceniać również na podstawie korelacji między wyceną franka i euro w Polsce a innymi walutami (tabela 3).

Tabela 3. Korelacje między kursami walut w Polsce

\begin{tabular}{|c|c|c|c|c|c|c|c|c|}
\hline \multirow{2}{*}{ Zmienna } & \multicolumn{8}{|c|}{$\begin{array}{c}\text { Korelacja porządku rang Spearmana kursy walut 2004-2012 } \\
\text { Oznaczone wsp. korelacji są istotne } z \mathrm{p}<, 05000\end{array}$} \\
\hline & 1 USD & 1 EUR & $1 \mathrm{CZK}$ & 100 JPY & 1 NOK & 100 HUF & 1 SEK & $1 \mathrm{GBP}$ \\
\hline 1 USD & 1,000000 & 0,776936 & 0,174821 & 0,594858 & 0,752443 & 0,523958 & 0,696067 & 0,672633 \\
\hline 1 EUR & 0,776936 & 1,000000 & 0,567519 & 0,783910 & 0,832971 & 0,540346 & 0,705118 & 0,376689 \\
\hline $1 \mathrm{CZK}$ & 0,174821 & 0,567519 & 1,000000 & 0,789676 & 0,524572 & $-0,210236$ & 0,329183 & $-0,391633$ \\
\hline $100 \mathrm{JPY}$ & 0,594858 & 0,783910 & 0,789676 & 1,000000 & 0,815596 & 0,104977 & 0,685941 & $-0,011882$ \\
\hline $1 \mathrm{NOK}$ & 0,752443 & 0,832971 & 0,524572 & 0,815596 & 1,000000 & 0,347558 & 0,867324 & 0,388904 \\
\hline 100 HUF & 0,523958 & 0,540346 & $-0,210236$ & 0,104977 & 0,347558 & 1,000000 & 0,380788 & 0,668032 \\
\hline 1 SEK & 0,696067 & 0,705118 & 0,329183 & 0,685941 & 0,867324 & 0,380788 & 1,000000 & 0,555615 \\
\hline $1 \mathrm{GBP}$ & 0,672633 & 0,376689 & $-0,391633$ & $-0,011882$ & 0,388904 & 0,668032 & 0,555615 & 1,000000 \\
\hline $1 \mathrm{CHF}$ & 0,550599 & 0,794953 & 0,798253 & 0,974370 & 0,849562 & 0,144053 & 0,737069 & 0,009093 \\
\hline
\end{tabular}

Ź r ó d ł o : opracowanie własne na podstawie średnich kursów NBP.

W okresie styczeń 2004-wrzesień 2012 kurs euro pozostawał najsilniej skorelowany z kursem korony norweskiej, natomiast kurs franka z kursem jena japońskiego 5 . 0 ile korelacja kursu korony norweskiej i euro potwierdza krosowe kwotowanie NOK/PLN przez euro, o tyle silna korelacja franka i jena może być uzasadniona wykorzystaniem tej pierwszej waluty do spekulacji,

${ }^{5}$ Ze względu na fakt, że rozkład kursów walut nie jest rozkładem normalnym, do badania korelacji wykorzystano współczynnik korelacji porządku rang Spearmana zamiast współczynnika korelacji liniowej Pearsona. 
zwłaszcza w transakcjach carry trade, podobnie jak w przypadku pieniądza japońskiego ${ }^{6}$.

Zależności między poszczególnymi kursami walut można również przedstawić przez korelację między dziennymi stopami zmiany kursu w okresie styczeń 2004-wrzesień 2012 (tabela 4).

Tabela 4. Korelacje dziennych stóp zmiany kursu walut obcych w Polsce

\begin{tabular}{|l|c|c|c|c|c|c|c|c|c|}
\hline \hline \multirow{2}{*}{ Zmienna } & \multicolumn{7}{|c|}{ Korelacja porządku rang Spearmana (dzienna stopa zmiany kursu 2004-2012) } \\
\cline { 2 - 10 } & Oznaczone wsp. korelacji są istotne z p <,05000 \\
\hline \hline 1 USD & 1,000000 & 0,717153 & 0,531486 & 0,783935 & 0,515420 & 0,154857 & 0,519411 & 0,713490 & 0,683172 \\
\hline 1 EUR & 0,717153 & 1,000000 & 0,740707 & 0,734180 & 0,704237 & 0,336778 & 0,730730 & 0,722337 & 0,883264 \\
\hline 1 CZK & 0,531486 & 0,740707 & 1,000000 & 0,548218 & 0,524625 & 0,374758 & 0,573387 & 0,534154 & 0,666839 \\
\hline $100 \mathrm{JPY}$ & 0,783935 & 0,734180 & 0,548218 & 1,000000 & 0,496207 & 0,141004 & 0,504296 & 0,653492 & 0,772119 \\
\hline 1 NOK & 0,515420 & 0,704237 & 0,524625 & 0,496207 & 1,000000 & 0,322914 & 0,725307 & 0,572293 & 0,637357 \\
\hline 100 HUF & 0,154857 & 0,336778 & 0,374758 & 0,141004 & 0,322914 & 1,000000 & 0,336676 & 0,247685 & 0,247730 \\
\hline 1 SEK & 0,519411 & 0,730730 & 0,573387 & 0,504296 & 0,725307 & 0,336676 & 1,000000 & 0,567268 & 0,631781 \\
\hline 1 GBP & 0,713490 & 0,722337 & 0,534154 & 0,653492 & 0,572293 & 0,247685 & 0,567268 & 1,000000 & 0,677384 \\
\hline 1 CHF & 0,683172 & 0,883264 & 0,666839 & 0,772119 & 0,637357 & 0,247730 & 0,631781 & 0,677384 & 1,000000 \\
\hline \hline
\end{tabular}

Źr ó d ł o : opracowanie własne na podstawie średnich kursów NBP.

W tym przypadku widoczna jest najsilniejsza zależność między zmiennością franka i euro, niemniej jednak w przypadku tej pierwszej waluty należy również podkreślić silny związek ze zmiennością jena, co dodatkowo potwierdza spekulacyjny charakter waluty szwajcarskiej.

Dodatkowe badanie zmienności walut kredytowania na tle innych walut wycenianych w Polsce można przeprowadzić na podstawie porównania modułu dziennych stóp zmiany kursu (tabela 5).

${ }^{6}$ Spekulacyjny charakter franka i jena wynika z historycznie niskiego poziomu oprocentowania tych walut. 
Tabela 5. Korelacja modułu dziennych stóp zmiany kursów walut obcych w Polsce

\begin{tabular}{|l|c|c|c|c|c|c|c|c|c|}
\hline \hline \multirow{2}{*}{ Zmienna } & \multicolumn{7}{|c|}{ Korelacja porządku rang Spearmana (moduł dziennych stóp zmiany kursu 2004-2012) } \\
\cline { 2 - 11 } & Oznaczone wsp. korelacji są istotne z p <,05000 \\
\hline \hline 1 USD & 1,000000 & 0,508283 & 0,301835 & 0,561403 & 0,304090 & 0,156776 & 0,307028 & 0,493467 & 0,464258 \\
\hline 1 EUR & 0,508283 & 1,000000 & 0,511615 & 0,489210 & 0,492352 & 0,293187 & 0,543976 & 0,506828 & 0,725744 \\
\hline 1 CZK & 0,301835 & 0,511615 & 1,000000 & 0,331194 & 0,338388 & 0,245069 & 0,342625 & 0,308667 & 0,416148 \\
\hline 100 JPY & 0,561403 & 0,489210 & 0,331194 & 1,000000 & 0,254650 & 0,182194 & 0,273774 & 0,436373 & 0,538137 \\
\hline 1 NOK & 0,304090 & 0,492352 & 0,338388 & 0,254650 & 1,000000 & 0,196554 & 0,487261 & 0,321873 & 0,417449 \\
\hline 100 HUF & 0,156776 & 0,293187 & 0,245069 & 0,182194 & 0,196554 & 1,000000 & 0,210287 & 0,186777 & 0,260171 \\
\hline 1 SEK & 0,307028 & 0,543976 & 0,342625 & 0,273774 & 0,487261 & 0,210287 & 1,000000 & 0,361754 & 0,425331 \\
\hline 1 GBP & 0,493467 & 0,506828 & 0,308667 & 0,436373 & 0,321873 & 0,186777 & 0,361754 & 1,000000 & 0,484745 \\
\hline 1 CHF & 0,464258 & 0,725744 & 0,416148 & 0,538137 & 0,417449 & 0,260171 & 0,425331 & 0,484745 & 1,000000 \\
\hline \hline
\end{tabular}

Źr ó d ł o : opracowanie własne na podstawie średnich kursów NBP.

W przedstawionym powyżej badaniu najsilniejszą zależność obserwuje się między modułem zmiany kursu euro i franka, co potwierdza długoterminową zależność zmienności obu walut. Podobnie do oceny zmienności dziennych stóp zmiany kursu, relacja frank-euro reprezentuje najsilniejszy związek w zestawieniu wszystkich korelacji.

\section{ZAKOŃCZENIE}

Kredytowanie mieszkaniowe w walutach obcych upowszechniło się w Polsce w szczególności w latach 2006-2008. Skala i tempo rozwoju finansowania walutowego spowodowały, że rozważane kredyty stały się kluczowym rodzajem ekspozycji całego sektora bankowego, generujących nowe rodzaje ryzyka zarówno dla banków, jak i kredytobiorców. Kredyty walutowe w szczególności były zaciągane w warunkach skrajnie niskiego poziomu wyceny walut obcych, co było działaniem na szkodę klientów przez wystawienie ich na poważne ryzyko kursowe. Chociaż oprocentowanie oraz wysokość rat kredytów walutowych były w początkowym okresie istotnie niższe na tle kredytów spłacanych w polskich złotych, już pod koniec 2008 r. ryzyko wzrostu wartości walut obcych zaczęło materializować się w polskim sektorze bankowym. W szczególno- 
ści doprowadziło ono do znaczącego wzrostu obciążeń spłatą rat oraz wzrostu zadłużeń powyżej wartości zabezpieczenia (LTV > 100\%). To zjawisko spowodowało, że banki straciły możliwość realnego zabezpieczenia przed ryzykiem braku spłaty kredytów.

Problem oddziaływania ryzyka walutowego na polskich kredytobiorców i możliwość jego przekształcenia w ryzyko kredytowe staje się szczególnie istotny ze względu na dominację franka szwajcarskiego w strukturze walut kredytowania. Waluta szwajcarska jest powszechnie wykorzystywana do spekulacji na rynku walutowym, charakteryzuje się wysoką zmiennością notowań oraz generuje wyższe ryzyko kursowe na tle innych głównych walut światowych. Wycena franka jest determinowana nie tyle kondycją gospodarki szwajcarskiej, ile ogólną sytuacją na światowym rynku finansowym, w tym zwłaszcza w strefie euro. Przewidywanie poziomu wyceny franka, jak i jego zmienności staje się zatem szczególnie skomplikowane. Długotrwałe utrzymywanie się recesji w strefie euro, a przy tym wysokiej wyceny franka będzie powodowało zarówno wzrost niepewności co do rzeczywistej możliwości spłaty mieszkaniowych kredy tów walutowych w Polsce, jak i konieczność stosowania dodatkowych zabezpieczeń.

Pozytywną tendencją widoczną w zakresie kredytowania mieszkaniowego w Polsce jest niewątpliwie zastępowanie franka polskim złotym i walutą europejską, co częściowo zredukuje ryzyko rynkowe zarówno po stronie klientów, jak i banków, a tym samym zmniejszy podatność systemu finansowego w Polsce na zawirowania międzynarodowego rynku finansowego. Z punktu widzenia stabilności polskiego systemu finansowego optymalne byłoby zastępowanie kredytów we franku kredytami w euro, dzięki czemu bankom byłoby łatwiej domykać pozycje długie, a klientom krótkie. Z powodu małej płynności i braku korzystnych źródeł finansowania do portfela kredytowego nie powinny być włączane inne waluty, jak np. korona norweska czy szwedzka, mimo niskiej zmienności ich kursów.

Ze względu na duże ryzyko wynikające z udzielania kredytów mieszkaniowych w walutach obcych, w tym: dodatkowe obciążenie funduszy własnych banków, możliwość niekontrolowanego wzrostu podaży pieniądza, podwyższenie obciążeń finansowych kredytobiorców, a także wobec braku realnego zabezpieczenia ekspozycji kredytowych na finansowanych nieruchomościach, rozważane kredytowanie najprawdopodobniej zostanie ograniczone do grupy wybranych klientów. Jednocześnie można oczekiwać, że utrudniony dostęp do kredytów tego typu i nacisk na udzielanie wyżej oprocentowanych kredytów 
w polskich złotych będzie oddziaływał na obniżkę cen i spowolnienie rozwoju rynku nieruchomości w Polsce.

\section{IIITERATURA}

Buszko M. (2010), Ryzyko kredytów walutowych i metody jego ograniczania na polskim rynku finansowym, Toruńskie Studia Międzynarodowe, nr 1 (3): Międzynarodowe stosunki ekonomiczne, P. Siemiątkowski (red.), Wydawnictwo Naukowe UMK, Toruń.

Buszko M. (2011), Zarządzanie kredytowymi ekspozycjami dewizowymi - perspektywa klientów banku, Acta Universitatis Nicolai Copernici. Zarządzanie XXXVIII, z. 404, Toruń.

Raport o sytuacji banków w 2008 r. (2009), Urząd Komisji Nadzoru Finansowego, Warszawa.

Raport o sytuacji banków w 2009 r. (2010), Urząd Komisji Nadzoru Finansowego, Warszawa.

Raport o sytuacji banków w 2010 r. (2011), Urząd Komisji Nadzoru Finansowego, Warszawa.

Raport o sytuacji banków w 2011 r. (2012), Urząd Komisji Nadzoru Finansowego, Warszawa.

Raport o sytuacji banków w I półroczu 2012 r. (2012), Urząd Komisji Nadzoru Finansowego, Warszawa. 